\title{
THE NECESSITY AND EFFICIENT USAGE OF MANAGERIAL COMMUNICATION WITHIN ORGANISATIONS DURING CRISIS SITUATIONS. DRAWING-UP THE CONTENT OF A CRISIS PLANNING
}

\author{
Elida-Tomiţa Todăriţă ${ }^{1}$ \\ Diana Elena Ranf ${ }^{2}$
}

\begin{abstract}
Managerial communication is a competitivity factor and an organisation's strategic advantage. Crisis management tries to prevent and diminish the crises' negative effects and protect the organisation. This field of activity has met a rapid development during the last years, as far as practical explanations and research are concerned.

The present paper outlines the rapid development of crisis management, as well as the causes that have generated this process within organisations. The purpose of the paper is to show how organisations manage crises, how they evaluate risks and also the stages of the communication crisis planning. At the same time, the content of a crisis planning shall be established, regarding the relationship with the press in crisis situations for some companies, mentioning the fact that this planning scheme could be used by any organisation, regardless of the field of activity.
\end{abstract}

Key words: managerial communication, crisis management, crisis planning, crisis situations, organisation

JEL codes: $M 11$

\section{Introduction}

"In times of crisis, successful companies differentiate themselves through the way they know how to re-create value", Michael Porter.

Any institution or organisation might face a crisis situation, capable of endangering its normal development and the reputation it enjoys in a particular society. Some crises are predictable and they can be prevented, others can not be anticipated and, therefore, prevented. Experience has proven that, besides all technical, economic, financial or educational precautions taken for stopping or controlling a crisis, it can always get out of hand and grow bigger. Under these circumstances, the crisis might seriously harm the organisation, unless it is properly managed from all points of view.

Commnunication is extremely important during the crisis, being able to soften, or even prevent the public's negative reactions. Most scientific fields have elaborated their own belief regarding crises.

Economists, for example, analyse the crisis according to specific criteria, assigning it the characteristics of phenomena with unfortunate consequences to the involved organisations, institutions and social groups: inflation, unemployment, recession.

\section{Types of crises that might occur in an organisation}

The ways in which commnunication can be improved within a company are numerous.

The types of crises can be determined according to the criteria applied for their classification:

\footnotetext{
${ }^{1}$ Romanian-German University of Sibiu, Calea Dumbrăvii nr. 28-32, tel. 0269233 568, e-mail: rectorat@roger-univ.ro

${ }^{2}$ Romanian-German University of Sibiu, Calea Dumbrăvii nr. 28-32, tel. 0269233 568, e-mail: rectorat@roger-univ.ro
} 
1. According to the type of solutions and how they can be solved, we can identify:

a) development crises: the organisation is dealing with alternative situations to the traditional solutions of handling conflicts, due to the new informational abilities;

b) legitimacy crises: the organisation sticks to the same solution that has achieved its functional limits);

c) honesty crises (the organisation's managers, even though they have competitive possibilities to process the information, they use it inappropriately, either to get some personal advantages, or for other hidden purposes, therefore endangering the organisation's image;

d) competence crises (crises of management misconduct): the organisation's managers are incapable of processing the information at the level of the possibilities offered by the informational techniques where they operate;

2. According to the medium, we can identify two types of crises:

a) internal crises, both at the organisation's level or its social environment, and at the level of some departments, reaching the branch or even the state level;

b) external crises, seen outside organisations, specific fields or the national territory.

3. According to the field the crisis occurs in:
a) political crises;
b) economic crises;
c) cultural crises;
d) communication crises;
e) image crises.

4. According to the emergency of their resolution:

a) immediate crises;

b) urgent crises;

c) steady crises.

The communication crisis means interrupting or confusing the informational flows within the organisation, between the organisation and the extra-organisational environment which makes dialogue and negociation impossible and has as purpose the confrontation within the communicational space till the point of losing the organisational and communicational identity.

\section{Communication crisis characteristics}

The communication crisis can be a component of the organisational crisis or of the powerful and sudden changes of a country's economy. It can precede, accompany or amplify the organisation's structural crisis. A defective internal communication regarding the organisation's changes and perspectives often leads to a major conflict between the company's members and the management, most often it deteriorates into an organisational crisis. Likewise, an incoherent, ambiguous and contradictory external communication, regarding the purposes and manners to achieve them may place the organisation in a conflict situation with one or more organisations from the same field of activity. Therefore, we can outline, for example, the organisations that have not shared to the public the level of risk about their activity or the products offered on the market (nuclear stations, chemical product factories) and whose characteristics could harm the environment, the peoples' health and safety.

Moreover, the communication crisis has an unpredicted, surprising and complex evolution, according to the factors that have led to its release. Its evolution can be slow, if hidden by the market success of the organisation's products or services or by the image promoted by its leaders. Under other circumstances, the communication crisis evolution can be sudden and devastating, if contradictions and differences that degenerate into conflict come along inside the organisation or outside of it.

All these statements rely upon causes which can generate the appearance of a communication crisis, undoubtedly causes which can be of internal or external nature. 
The internal causes, of primary interest, are:

a) the inexistence or inobservance of certain norms and rules of internal communication: vertically (information, decision communication, training, imaging, organisational culture motivation and promotion) or horizontally (cooperation, mutual knowledge);

b) communication interruption or message distortion due to the employed communication channels, with unfortunate consequences on the communication efficiency and determining a specific status inside the organisation and its external environment;

c) the existence of certain obstacles in the communication process due to the interpretation beliefs, language and background barriers;

d) The managers' interpersonal communication styles: the autocrat, who communicates a little and is not interested in feed-back; the fake democrat, who sends few information, but facilitates getting a great number of feed-backs; the politician, who sends a lot of information, but who uses feed-back only to select what corresponds to the ideas sent by him; the communicator, who establishes a balanced communication, adjusting his decisions according to the information he receives;

e) The existence of an inadequate setting for developing informal communication among the members of the organisation and the reduced existence or inexistence of policies, strategies and departments dedicated to internal and external communication.

Here could be the external causes:

a) the existence of a large amount of information, in a very short period of time, on various channels, which exceeds the processing and control capacity of the information useful to the organisation;

b) the existence of an intended disorder of the organisational communication by manipulating peoples' perceptions and representations regarding their place and purpose within the production, decision and control process;

c) the intended actions to diminish the official communication credibility of an organistion, through public mediatised declarations;

d) the existence of striking hostilities towards an organisation which has as a result shutting off access to information sources and communication channels.

\section{Crisis management}

Crises appear as phenomena that might harm the organisation, considering both the material losses, as well as the social reputation, by deteriorating the public image. Under these circumstances, the crisis response programmes, thought of and applied, have to be based on different communication strategies, able to influence the public and change the way it interprets this crisis.

The falling of some funds or pyramidal games, bankruptcy or some banks' lack of liquidities, terrible floods, fires, water pollution, violent demonstrations, consequtive epidemics, diploma scandal, are only some examples from the hundreds of cases experienced by the contemporary Romanian society, which underlines the fact that this period is one shaken by many crises. Nowadays, the crisis, regardless of the field, economic, cultural, social etc. has become an ordinary estate, and the word has entered into the current vocabulary of institution leaders, journalists and even the wide public.

The almost permanent presence of crises, present in different institutions, as well as the need to understand, to anticipate and to control them has made it for many leaders, managers, management specialists and public relations practitioners to be concerned about "managing the crises", "crisis management", "crisis communication".

Any organisation can be faced with a crisis situation capable of endangering its usual activity and the reputation it enjoys within a particular community. 
Good communication during crisis can soften and even prevent the public's negative reactions. During the crisis, other representations and "symbols" are imposed and "stereotypes" are established, which will, for a long time, remain associated to that organisation's image. Thus, the organisation's management, together with the public relations department, has to be prepared to handle some unexpected situations.

Managerially, communication is an instrument by means of which the manager sends and receives information and decisions, accepts or denies certain solutions, plans, organises, carries off, controls, prepares and implements change. There is a correlation between communication and the manager's role which will be outlined in Table no. 1.

Table no. 1

The correlation communication-manager's role

\begin{tabular}{|c|c|c|}
\hline Field & Role & Communication activities \\
\hline \multirow{3}{*}{ 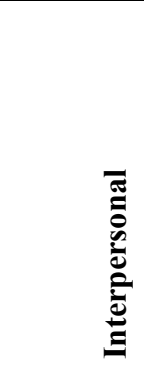 } & Representation & $\begin{array}{l}\text { - communication through its own image } \\
\text { - attending different events } \\
\text { - image creation } \\
\text { - influencing the development of certain activities }\end{array}$ \\
\hline & Leader & - ensuring the authority-responsibility correspondent \\
\hline & People contractor & $\begin{array}{l}\text { - estabilishing interviews } \\
\text { - solving certain problems } \\
\text { - convincing and influencing certain employees } \\
\text { - explaining some decisions }\end{array}$ \\
\hline \multirow{3}{*}{ 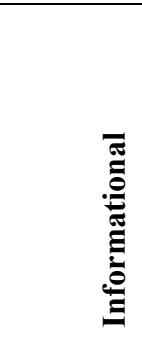 } & Survey instrument & $\begin{array}{l}\text { - discussions with employees } \\
\text { - recognising good results } \\
\text { - criticising the mistakes } \\
\text { - discussing sollutions }\end{array}$ \\
\hline & Disseminator & $\begin{array}{l}\text { - sending information } \\
\text { - processing and storing information }\end{array}$ \\
\hline & Spokesman & $\begin{array}{l}\text { - communication with employees } \\
\text { - mass-media communication } \\
\text { - attending different events }\end{array}$ \\
\hline \multirow{4}{*}{ 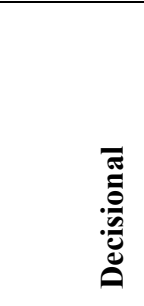 } & Enterprising & - taking decisions \\
\hline & Problems solver & $\begin{array}{l}\text { - solving conflicts } \\
-\quad \text { discussing strategic and tactical problems, } \\
\text { inclusive during crisis situations }\end{array}$ \\
\hline & Resource granter & $\begin{array}{l}\text { - taking decisions } \\
\text { - interpreting and implementing decisions }\end{array}$ \\
\hline & Negociator & $\begin{array}{l}\text { - negociating contracts } \\
\text { - establishing agreement when taking decisions }\end{array}$ \\
\hline
\end{tabular}

Source: drawn up by the author of the paper

\section{Elaborating a crisis management planning}

The training techniques in case of crisis situations, the people that should be involved in this kind of activities, the necessary strategies, the implementation stages and methods, the communication strategies that could be employed both inside and outside the organisation become more and more important in a society wrapped in an economy of crisis. To control such events one must base on elaborationg a crisis management planning.

It comprises a complete list of procedures that have to be applied in all fields of activity that might be affected by the different crises.

This palnning represents an essential working instrument because crises in an organisationa are events that that take place under time pressure and where rapid answers are vital.

A crisis management planning contributes to response time decrease, by offering the necessary context information, identifying responsibilities and assigning specific tasks to some well-established persons. Besides the speed factor, this planning offers a system that could save 
lives, decrease the exposure of some organisations to risk factors and could allow for helping actions to be taken without thorough analyses.

An organisation facing a crisis is concerned with its own behaviour, its members' behaviour and the behaviour of all its other categories of public.

For example, in 1996, according to a research of the Crisis Management Institute, one aspect of the crises shows that only $14 \%$ appear indeed abruptdly, are accidental and unexpected, the rest of $86 \%$ being more or less predictible, being the result of operational or organisational weaknesses or of incorrect practices.

S. Fink once suggested a crisis diagram based on two axes, elaborated by him: crisis impact value and crisis probability factor.

On the first axis, the importance of the crisis is determined by five questions:

1. If a crisis risks to grow in intensity, how big is this intensity and how fast can the increase happen?

2. How much will the crisis become interesting for the involved public?

3. How will the crisis change the organisation's normal activities?

4. In what way is the organisation guilty for starting the crisis?

5. In what way is the organisation affected by the respective crisis?

On the second axis, the crisis probability is represented on a scale from 0 to 10 , where 0 is zero probability for a crisis to happen, and 10 the doubtlessness of a crisis to happen. The two axes, each divided in ten units, form, by their intersectation, a "crisis barometer".

Controlling such events is based on the elaboration of a Crisis Management Planning. This includes a complete list of training practices (Fig. no. 1) that should be apllied in all departments on which the effects of the different crises might act. Such a planning represents an essential working instrument.

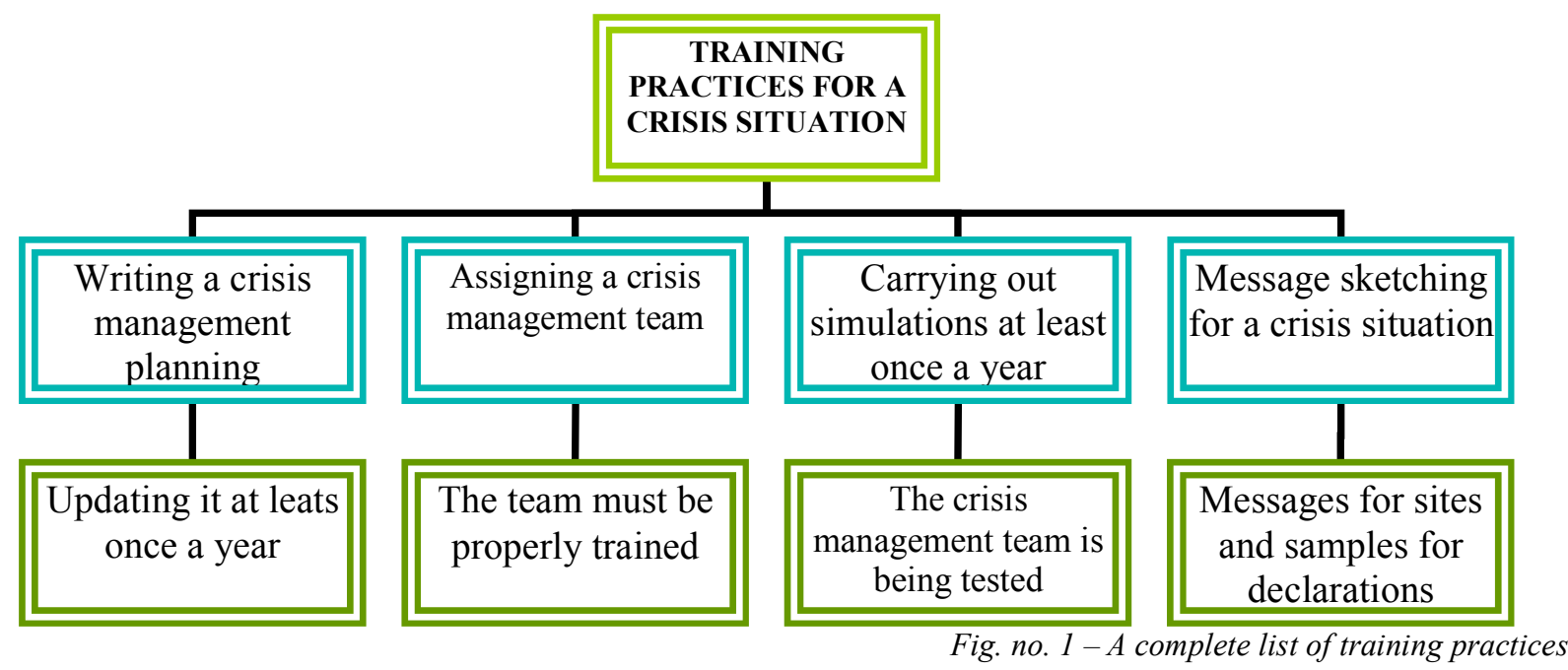

\section{Crisis Communication Planning (CCP)}

For an efficient crisis management, a crisis communication planning (CCP) needs to be established, even during the calm periods. This is accomplished by public relations specialists who, according to all authors in the crisis management field, have to be involved in all stages and all events related to a crisis.

Ussually, the CCP looks like an instructions' file. It has to be set up so that relationists easily find the specific sections. Moreover, it has to resist to the unpredicted situations of certain crises, thus it is not recommended to keep it only on the computer, as it might be hit by fires, earthquaques or even simple power cuts. The Crisis Communication Planning regards the same public of an organisation which is also regarded by the usual communication campaigns. An 
organisation must have various $\mathrm{CCP}$, according to the different types of known crises. These plannings facilitate communication with the different types of publics. However, they are not yet magic formulas that ensure a safe success, but only a flexible action guide, which organises the communication actions and shapes.

\section{A crisis palnning's model (Fig. no. 2):}

1. The cover: contains the planning's title and the date it was elaborated or revised. On the cover we mention the fact that the document is of internal usage (private) and that unauthorised multiplication or release is forbidden;

2. The introduction: this document has to be written by one of the organisation's leaders. It underlines the importance of the crisis planning, it reveals the estimated results and it draws attention on the indispensability to regard that planning' stipulations;

3. Purposes and objectives: show the organisation's action principles during crisis and the policies through which these principles are to be achieved. Here, we can mention those information or policies which, for reasons different from one organisation to another, can not be made public;

4. The crisis cell structure: the document includes the names of the cell's members, their range of competence, their mission within the cell, the addreses and phone numbers. Another list can be added to this one, which includes the outside specialists or consultants who can be consulted. The crisis cell is a cross and functional group, which includes the people assigned to handle any type of crisis. It has three major tasks: to draft a Crisis Management Planning; to implement this palnning; to react efficiently to the unexpected and unincluded problems in the planning. There is no planning that could anticipate all details of a crisis, therefore the crisis cell has to be able to offer solutions to the problems it could not foresee, but that could come up at any time in a real crisis. The crisis cell is led by a crisis manager (usually the public relations head of department), which collaborates with the organisation's management, conducts the work of the other team members and takes decisions, conceives, sketches and verifies the texts that have to be sent. The crisis cell also includes a manager's assistant, a coordinator of the crisis control center, and other public relations specialists with various responsibilities. Obviously, the structure of this team will be different from one event to the other. The given list also includes each team's member during the crisis.

5. The statements: the crisis cell members and the organisation's management sign as recognition and hold responsible to comply with the crisis management planning's and crisis communication's stipulations.

6. The crisis simulation calendar: the activities and techniques estimated for the most probable crises have to be simulated at least once a year, if not even more often. Although during a real crisis different ways to act may appear, these simulations allow to verify the crisis cell training and the other members of the organisation's ability to react.

7. The list of the involved public: the document includes inside and outside public with which communication must be held during crisis (the members of the Managing Board, the stockholders, the business partners, the investors, the clients, the suppliers, the employees, the leaders of the community the organisation operates in, organisations of the same profile, massmedia, unions, governmental personalities etc.).

8. Means of information for the involved public: in order to ensure the efficient sending of information, the completion of a specific information system is required, with the adequate technical transmission coverage, which have to be perfected for each type of public (the phone for th management members: the meetings or the display for employees: the fax, e-mail or phone for the mass-media).

9. The spokesman during the crisis: the person assigned for this job has to manage the messages' consistency and accuracy sent by the organisation to its audience. He must be a good communicator, both inside the organisation and the team he works with, as well as in the relations to journalists. He has to be carefully chosen, because, for an audience, he represents the 
organisation or the company. Moreover, he has to know all aspects of the crisis, to understand its implications, to have the responsibility and authority to talk for the organisation. He has to look like a rational person, concerned about the organisation's problems, sensitive to the worries of the people affected by the crisis, determined to contribute to solving the created situation.

10. The Crisis control centre: the place where the activity of the crisis management team will develop. This centre includes at least two rooms, one of them big enough to be turned into a press conference room at any time and one intended fo the crisis cell work and, if necessary, for individual interviews requested by journalists. These rooms have to be well-equiped and operational. They must comprise enough tables and chairs, a copy machine, direct phones, faxes, video and audio equipment, network-connected computers, maps, phone books, pocket-books, writing materials (pens, pencils, paper). We must find here the updated press files, comprising documentary materials about the organisation, photos of its various departments or of the people from the organisation, statistics etc.

11. List of staff intervention: during a crisis situation, different emergency situations show up, this requires the involvement of some specialists from the most different fields of activity. Such a list includes phone numbers, addresses and numbers of personalities in the fire departments, ambulance service and hospitals, police, prosecutor's office, water administration, electricity etc. It is useful to have the information about governmental representatives and the local administration.

12. The crisis files: next to personalities, journalists are the next audience that has to be informed about the crisis. Any public relations department or any press office of an orgnisation has to have updated press files. In crisis situations, these documents are all the more important as the event is more severe.

13. Data banks: under the pressure of the crisis, it is difficult to get statistical or filed data; therefore, it is better for those to be already grouped in documentary files. In this category there are materials such as annual reports, procedure manuals or security and quality manuals, the organisation's history, short biographical documents of the leaders, photos, addresses of the organisation's immovables and their map, data regarding the number of employees and the organisational structure.

14. Messages: For each category of audience, a particular message has to be created, according to the interests and level of commitment of each audience of the organisation. Besides, a common statement for all types of audiences must be predicted, mentioning the nature of the crisis, the basic data about it, the measures taken by the organisation to stop or diminish the crisis, the losses, the affected victims or people, the impact upon the environment or other organisations.

15. The answer: if it is well-composed, or if the right decisions have been taken, in accordance to the strategies established by the $\mathrm{CCP}$, the organisation will be rewarded by limiting the crisis' negative effects and maintaining the confidence of key-public types. Now, it is essential for the company to react immediatedly and to send to all types of public affected or interested by the crisis an initial response: this is usually represented by the first statement of the spokesman. The answer does not only have to be immediate, but also consistent: it has to include exact information, non-contradictory (that is why it is necessary for the organisation to express itself only through the voice of the spokesman), of practical nature (where practical consequences of the crisis and immediate measures should be shown).

We should not forget the fact that, a CCP is a guide that states the major actions. There are unpredictable factors in every crisis. 


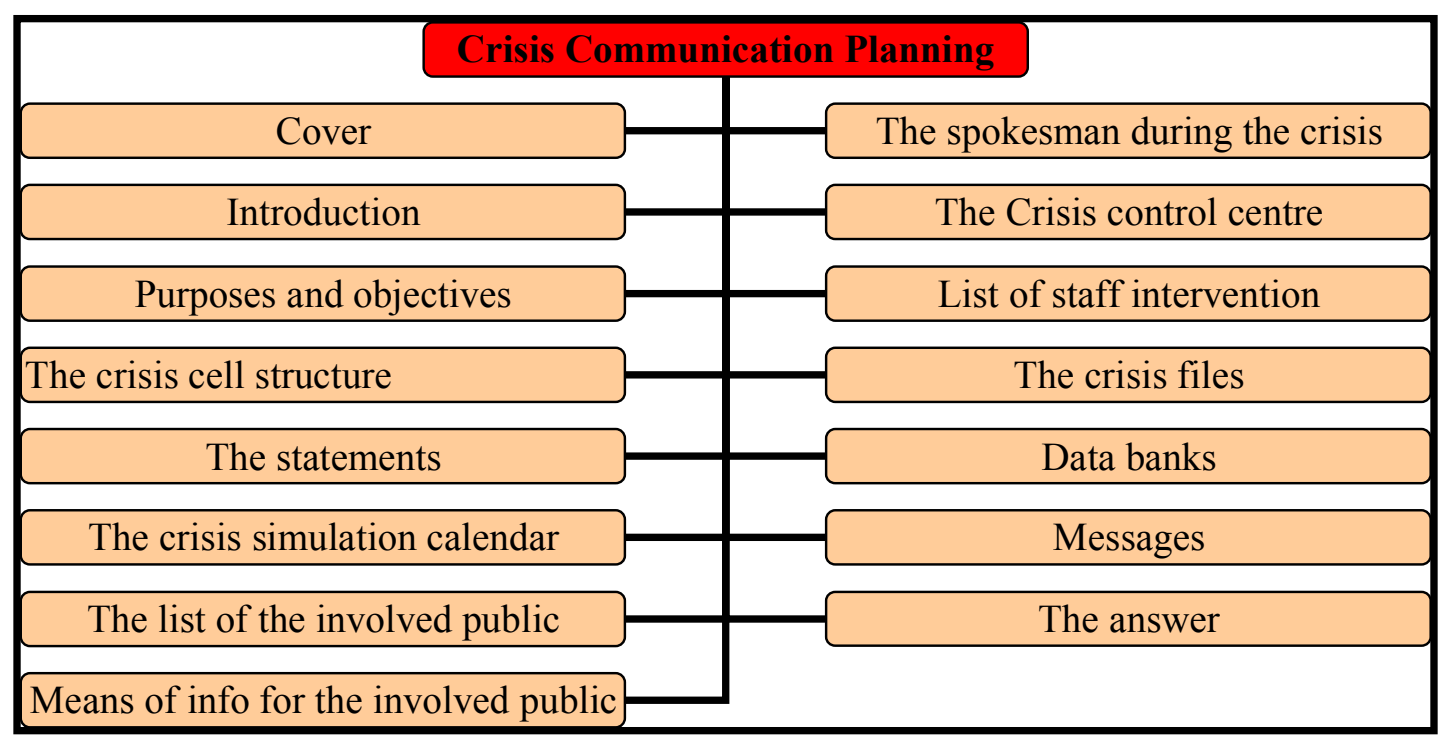

Fig. no. 2 - A crisis palnning's model

\section{Managing the crisis}

The crisis management can not be improvised: on the contrary, it is built on the correct evaluation of circumstances and mastering some adequate answer strategies, prepared startegies and even experienced long before the beginning of the crisis. High-profile or strong impact events: accidents, terrorist attacks, natural disasters are realities that might confuse even the best positioning or planning. If in this case, risk management strategies no longer work, crisis management strategies apply. The conflict management process, which includes handling permanenet problems and risk communication efforts, is strongly tested in crisis situations, when a high level of uncertainity installs.

\section{Conclusions}

The purpose of the paper is to outline the basic elements of the communication management during crisis, to identify the communication problems in this matter but also to establish a crisis communication planning to fit any organisation, regardless of its field of activity. The displayed crisis communication planning is a pattern that covers the organisations' needs to surpass a particular moment of crisis. Moreover, it has been wanted to outline the informational framework to discover an improvement possibility of the communication process within organisations during crises, therefore a successful escape from the economy haunted by crisis.

The proper crisis management represents "a collection of measures, established from time, which allow the organisation to coordinate and control any emergency". The crisis management represents a set of factors conceived to fight crises and diminish losses caused by the crisis, it is a process of strategic planning, having the purpose to eliminate a part of the risk and uncertainity owed to the negative events and which thus allows the organisation to keep under control its evolution, all these being determined by an economy that is now beslaved to an entire process of crisis existence.

\section{References:}

1. Crisis Management: master the skills to prevent disasters, 2004. Harvard Business School, United States of America, pp. 90-110;

2. Desforges, A. K., 2008. Multimédia et Communication de crises. PowerPress Editions, Cote d'Ivoire, p. 22, pp. 39-43; 
3. Fink, S., 1986. Crisis Management: Planing for the Inevitable. Amacon, New York in Allinson, A. R., 2005. Saving human lives: lessons in management ethics. Springer Editions, Dordrecht, Netherlands, p. 69;

80 ;

4. Luchian, D., 1998. Managementul în perioade de criză. Editura Teora, Bucureşti, p. 55-

5. Niculae, T., Gherghiţă, I., Gherghiţă, D., 2006. Comunicarea organizaţională şi managementul situaţiilor de criză. Editura Ministerului Administraţiei şi Internelor, Bucureşti, pp. 127-155. 